\title{
Economic development leadership: 4 Cs for leadership success in Nunavut
}

\author{
Cheri Kemp-Long, Ec.D. (F)
}

\begin{abstract}
Economic development leadership is required at all levels of government- municipal, territorial and federal- to establish a sustainable economy. In Nunavut all communities are remote from the others - each in its own separate, yet connected, location with little 'relationship' with any others. There is a stated focus on community based and community driven economic development, yet very little understanding of what that really means. What is required for it to happen? How can cooperation and collaboration across levels of government assist? How would developments generate new wealth for Nunavut and Nunavummiut? It is argued in this paper that there is a need for the leadership at the three levels of government in Nunavut to understand their role in economic development and address through policy and process, the means to develop and implement action. In the context of this paper - leadership is defined as the ability to understand, analyze, direct and act in a manner appropriate to encourage, entice and invigorate others to follow.
\end{abstract}

Keywords: leadership, community economic development, cooperation, collaboration, northern Canada

\section{Background}

The Nunavut Territory was officially created on April 1, 1999 as a result of Article 4 of the Nunavut Land Claim Agreement (NLCA) signed on July $9^{\text {th }}, 1993$. The NLCA is an agreement signed by the Government of Canada, the Government of the Northwest Territories (GNWT) and the Inuit of the Nunavut area, as represented by the Tunngavik Federation of Nunavut (TFN) after more than 30 years of negotiation. Article 4 of the Agreement called for a separate Territory to be established along the boundaries of the NLCA. A Capital was chosen by the residents of Nunavut through a plebiscite and the first Members of the Legislative Assembly (MLAs) for Nunavut were elected in February of 1999 to sit at the $1^{\text {st }}$ session on April $1^{\text {st }}$.

Although the new Government of Nunavut had their administrative structure initiated by the Office of the Interim Commissioner (OIC) appointed by the Government of Canada, it had been outlined by two documents, Footprints in New Snow I and II. The underlying premise of the structure was to ensure that the people of Nunavut, especially the Inuit beneficiaries of the NLCA would receive maximum benefit from the creation of the Territory. A decentralized approach to the administration of the Government of Nunavut would establish headquarter functions in the ten largest communities (decentralized) and then work to ensure that the other 15 non-decentralized communities would benefit from other specific initiatives. The OIC dissolved 
in the summer of 1999 once the Government of Nunavut took on their role after April $1^{\text {st }}$. The ten largest communities are Pond Inlet, Igloolik, Pangnirtung, Cape Dorset, Rankin Inlet, Arviat, Baker Lake, Gjoa Haven, Cambridge Bay and Kugluktuk, plus Iqaluit as Capital.

\section{Figure 1. Nunavut regional map}

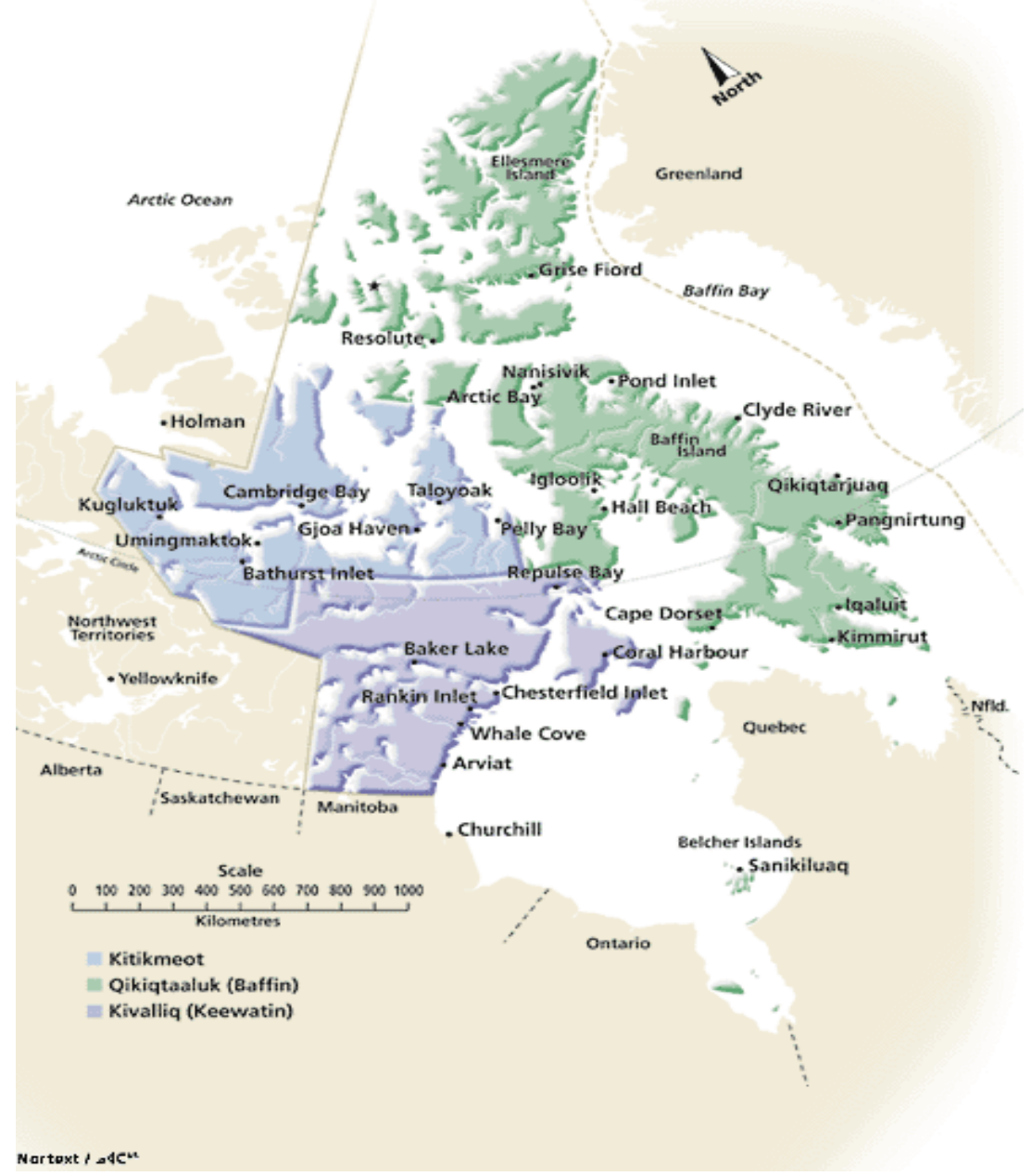

Source: Nunavut.com (n.d.). Map of Nunavut. Retrieved from

http://www.nunavut.com/nunavut99/english/map.html

The Inuit beneficiaries of the NLCA would also continue to receive benefits through Nunavut Tunngavik Inc, an entity created from the TFN once their responsibility for the negotiations of the NLCA were completed. Nunavut is such a large area - almost two million square kilometers or 1/5 of Canada - and has such diverse landscapes, wildlife and climates, and ranges across three timezones, Eastern, Central and Mountain, that functional regions have long since been established. The largest region is the Qikiqtani or Baffin on the eastern coast, north of Quebec and Ontario including 13 communities from as far south as Sanikilluaq in Hudson Bay to Grise 
Fiord on Ellesmere Island in the north. The central region is the Kivalliq or Keewatin on the west coast of Hudson Bay with six communities north of Manitoba. The western region of Nunavut is the Kitikmeot which is comprised of five communities along the Arctic Coast, Victoria Island and King William Island, north of NWT, Saskatchewan and Alberta. The 25 communities that house the 30,000 Nunavut residents are accessible only by air year round, and by sea during a short open water season; there are no roads to or within Nunavut, ranging across three timezones: Eastern, Central and Mountain. For both Government of Nunavut and Nunavut Tunngavik Inc representation and servicing there are regional offices established.

The Inuit of Canada, although aboriginal people, are not First Nations peoples and are therefore not included under the Indian Act. They do have a 'package' of benefits as aboriginal peoples, however they pay taxes like other Canadians and they live in communities that are municipal corporations rather than 'reserves'. The funds for the capital infrastructure, services and operations of those municipal corporations come as transfers from the Government of Nunavut (GN) within the transfer of dollars provided to the GN by the Government of Canada. Only one community in Nunavut charges taxes to its residents to cover a portion of its infrastructure, administrative and service delivery costs - the City of Iqaluit.

Within the financial settlement included as a component of the NLCA, funds were set aside by NTI to assist in the economic development of the Territory. Funding programs include assistance by way of grants, contributions and loans for business start-up and expansion, for artists, and to support training and post secondary education for their beneficiaries. The funds are provided to the three regional Inuit associations (RIAs) under NTI - one in each of the Kitikmeot, Kivalliq and Qikiqtani regions. In addition to the programs and dollars handled through each regional group - NTI also established the Atuqtuarvik Corporation which provides loans of significant size to Inuit owned business developments. The federal government under Indian and Northern Affairs Canada (INAC) has a suite of programs to assist aboriginal Canadians and aboriginal communities to develop their economies. In Nunavut, the program is administered through an arrangement with the same three RIAs on behalf of the 'aboriginal communities' in their respective regions. INAC has one office in Nunavut responsible for managing the department's range of programs for both aboriginal and non-aboriginal northerners. The office is located in Iqaluit.

There are a number of Institutes of Public Government also established as a component of the NLCA, one of which is the Nunavut Impact Review Board (NIRB). NIRB has the mandate for review of major development plans to consider the impacts on the beneficiaries of the land claim and then make recommendation to the INAC Minister on the issuance of a permit for the land use and the development. There is limited participation by the communities in this process as although the communities provide all services to the residents, and thus the beneficiary residents, they are not required to be engaged in the consultation/review process. Additionally, under the 
NLCA all developments are required to negotiate an Inuit Impact and Benefits Agreement with each regional beneficiary group where they plan to operate - the focus of which is jobs, training, and compensation for any negative impact on water, land or wildlife in the area. Communities are not part of the IIBA considerations, so impacts on the ability of a community to deliver appropriate services to residents impacted by the development are not compensated through that process.

In establishing the processes for day to day operational functions of the Government of Nunavut, many systems were adopted from those in place within the Government of the NWT (GNWT) at the time of division. One of those functions was the provision of community economic development services - or an economic development officer (EDO). In 1994, prior to the creation of Nunavut, the GNWT had initiated the transfer of community economic development functions from the territorial government to the municipal corporations. Each community was transferred the responsibility and an allocation of funds to manage their own EDO and local activities. The decision was made based on a response to an expressed interest from communities to have more say in what the GNWT did in their communities - the decision wasn't widely accepted in that frame of reference, some perceived it as 'off loading' rather than transferring. The GN completed the process in Nunavut and issued a contribution agreement annually for the delivery of the community economic development officer functions to each of Nunavut's 25 communities.

The result of the structure outlined above is shown in Figure 2 - the GN Department of Economic Development and Transportation (ED\&T) provides a contribution agreement to the community to hire an EDO to deliver government economic development programs on their behalf, and for some economic development planning and implementation at the community level. The GN Department of Community and Government Services (C\&GS) provides funds for the community to plan, administer, and deliver municipal services for the residents; many communities also are funded for a Lands Officer. NTI through the RIAs and their economic development organizations offers a range of business development programs for beneficiaries to access and has a contact person in each community for liaison between the organizations and the individuals. INAC and Human Resource and Service Development Canada (HRSDC) provide funds for the regional Inuit economic development organizations to also support community economic development. The flow chart below shows a significant amount of responsibility assigned to the community- a push not pull assignment of responsibilities, based on the focus on community based development which therefore requires community control. The majority of which is often assigned to the EDO to 'manage'. 
Figure 2: Community economic development partners

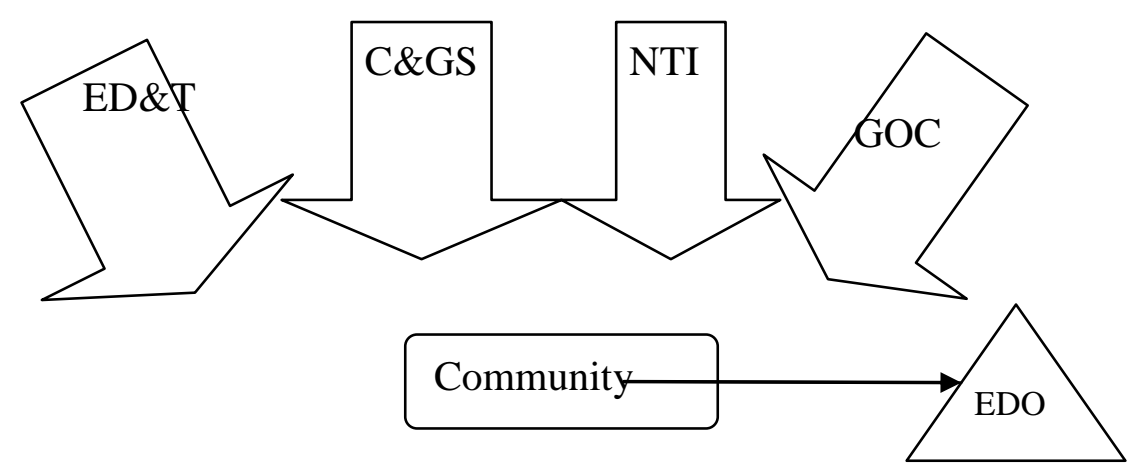

In 2003 the GN, NTI and INAC cooperated in holding a series of consultations toward the development of the Nunavut Economic Development Strategy (NEDS). The NEDS was written not only using the results of significant consultation across Nunavut, but also based on the Conference Board of Canada's first Nunavut Economic Outlook in 2001 and a re-issue in 2002 following the 2001 Census. NEDS outlines 13 strategic priorities grouped into four strategic planning areas: community economies, territorial economy, land, and people. Of the 172 action items identified in the Strategy, the members of the Nunavut Economic Developers Association (NEDA) determined that more than half would be the direct responsibility of the community EDO.

\section{Issues}

The communities, while having almost total responsibility for planning the Community Economic Development (CED) of their community, and in principle, being provided with the financial and human resources to do that, are not provided with the appropriate support to ensure success. Without the knowledge and expertise on municipal council or within municipal staff about the complexities of CED, they fall short of attaining the level of success that is possible. In a similar vein, the regional Inuit organizations and the territorial and federal government agencies and departments that provide the resources and expect results, also require the knowledge and expertise to support the work at the community level.

Although Community Economic Development is defined in a variety of terms around the world the overall message is the same, "CED is a community-based development approach that connects social, economic, environmental, and cultural goals for community well-being. It is social and economic development in the community, for the community, by the community. ${ }^{1,}$ Although communities in Nunavut are each remote from the other, there are a number of ways in

${ }^{1}$ GN Policy Definition 2003 
which each depends on a relationship for some components of their day to day lives. That relationship must be considered in the development plans for the individual community, and for the other communities within the relationship. The regional structure of both the Nunavut Government and the Inuit organizations provides a logical base for that planning, as does the reality of air transportation routes.

Air transportation routes for Nunavut are predominately north-south rather than east-west or intercommunity. Because of the flight routes, food supplies and health services are also linked north-south. See the two maps below as provided on the websites of the two major carriers flying within and into Nunavut, First Air (Figure 4), and Canadian North (Figure 3). The main routes into Nunavut are:

- for the Qikiqtani or Baffin region, jets come from Ottawa/Montreal into Iqaluit and then connect to smaller aircraft into the other communities in the region;

- for the Kivalliq or Keewatin region, the jet comes from Winnipeg to Rankin Inlet and then smaller planes to the regional communities; and

- for the Kitikmeot region travel is from Edmonton/Calgary and then Yellowknife to Cambridge Bay or Kugluktuk and then to the smaller communities, or from Yellowknife directly with a smaller regional aircraft.

Flights across Nunavut are only between Iqaluit, and Rankin Inlet and then by connecting through Yellowknife to Cambridge Bay or Kugluktuk; the most difficult being Cambridge Bay/Kugluktuk requiring an overnight in Yellowknife, NWT.

\section{Figure 3. Airline services to Nunavut by Canadian north}

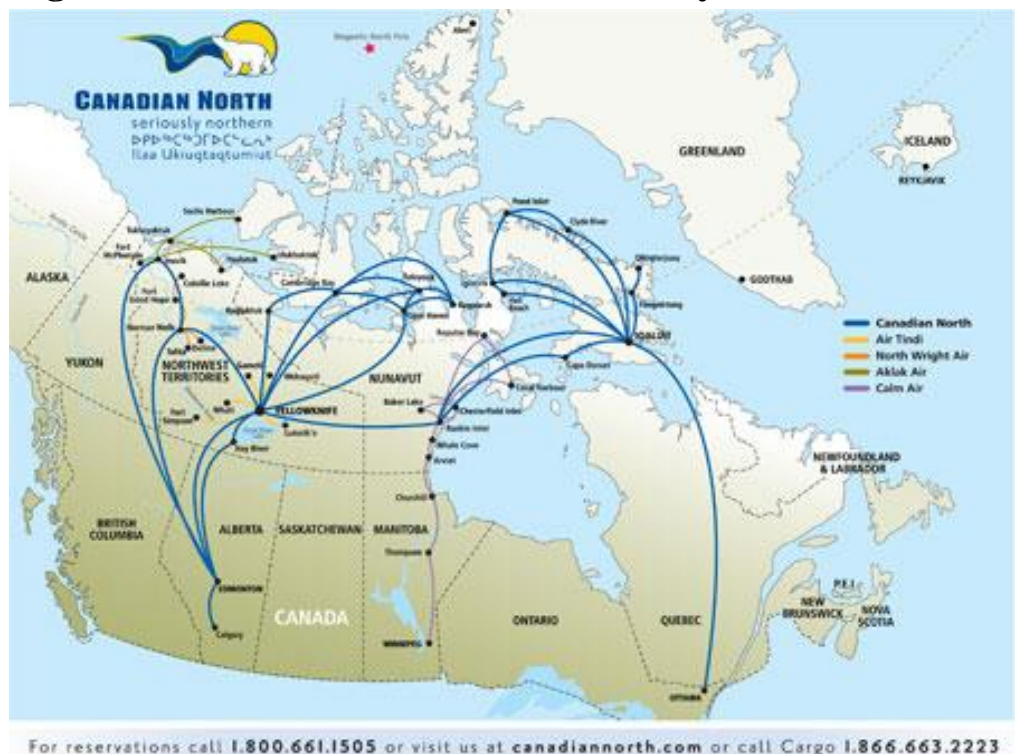

Source: Canadian North (2009). Route Map, Retrieved from http://www.canadiannorth.com/sites/default/files/u256/Route\%20Map\%2002-04-13.pdf 
Sea transport during the open water months of July through October has a similar north south relationship - the Kitikmeot is serviced by barge from Hay River/Yellowknife down the MacKenzie River and across the arctic coast; the Kivalliq receives supplies by barge from the Port of Churchill, MB; and the Qikiqtani region is serviced by freight ships from Valleyfield or the Port of Montreal in Quebec.

Figure 4. Airline services to Nunavut by First Air

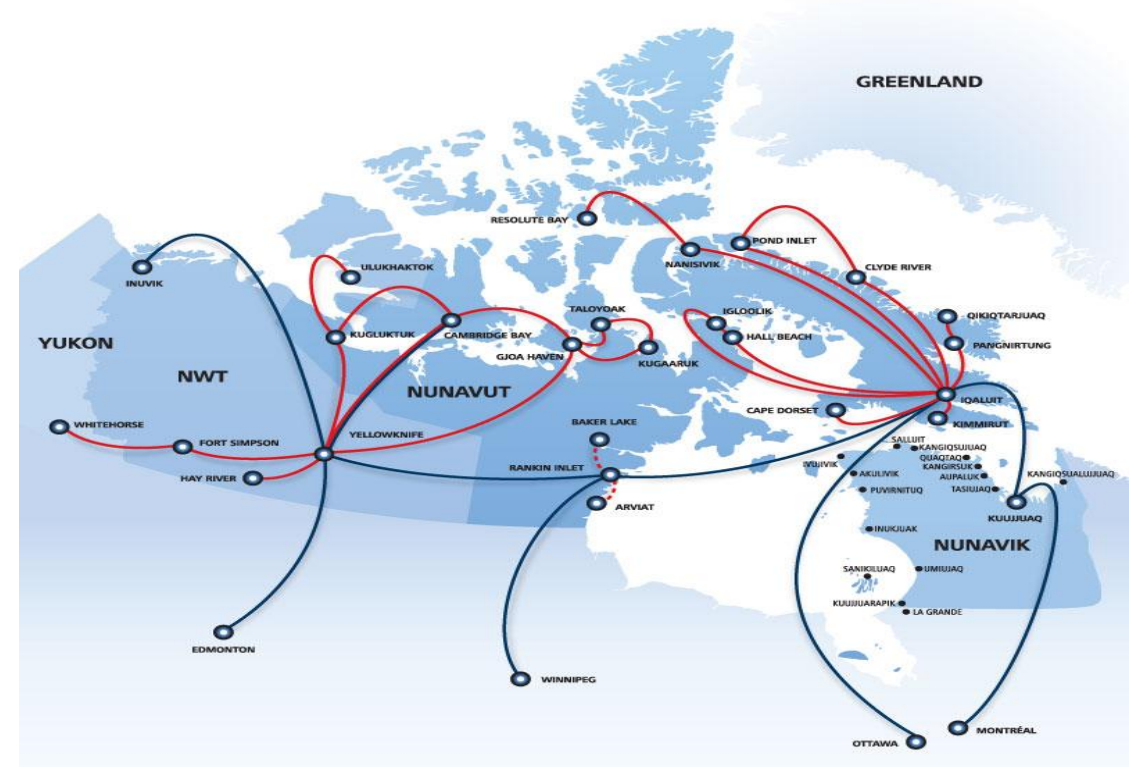

Source: First Air (2009). Route Map. Retrieved from http://firstair.ca/index_en.html

The realities of the transportation routes, while providing logistical links between communities, does not ensure that strategic planning will consider the relationship. With a focus on community based planning and development, the linkages are not often top of mind when considering initiatives; competition would be first, cooperation or collaboration much further down the list. Government programs and resources are also not structured for groups, or groupings of communities, instead they are specific to one community, or one at a time. When a coordinated approach is considered, it is often based on the regional structures rather than on a transportation, development or initiative basis. For instance, a mine development on the northern tip of Baffin Island brings four communities together to consider impacts and benefits - Pond Inlet, Arctic Bay, Igloolik and Hall Beach. It would have made sense to bring Iqaluit into the discussion as well considering that travel between the communities would be through the Iqaluit airport and some of the logistics services located there are likely to be accessed.

Government and Inuit organization programs often provide similar programming for development. Without significant on-going cooperation and collaboration with the communities at the local level, this may result in missed opportunities when conflicts arise regarding who 
could or should assist. For instance, if one agency has the ability to only fund planning, and another can support planning and establishment, the dollars could be best used if the proponent and potential funders considered the uses, their budgets and the requirements to cost share the project. Limited resources would achieve more with a shared approach, but that requires a very focused effort in cooperation which is not so easy when the organizations and individuals are at a considerable distance from each other.

Communities in Nunavut are Municipal Corporations under the GN Cities, Towns, and Villages Act- 24 range in size from 140 in Grise Fjord on Ellesmere Island in the high arctic to 2,400 in Rankin Inlet on the western coast of Hudson Bay; and one, the City of Iqaluit, capital of Nunavut with close to 7,000. Iqaluit is the only tax based community; the other 24 are funded through transfers from the GN for their operations and capital requirements. The leadership of all communities is by an elected Mayor and Council, who hire a Senior Administrative Officer who in turn hires staff to provide the municipal services - water, sewer and solid waste, roads, recreation and airport. The Mayor and Council are elected from among the residents of each community for two or three year terms on a staggered basis. The GN department of Community and Government Services provides support to the communities in their administrative functions, capital planning and management and election process.

The Government of Nunavut has 19 MLAs elected for four year terms from across Nunavut - the electoral boundaries are based loosely on a community by community basis, with a population base included to balance out the structure. The Premier and Cabinet are chosen from within the elected MLAs. The full Assembly elects the Premier and the Cabinet members, and then the Premier assigns the individual department portfolios. The Premier appoints Deputy Ministers per department and they in turn, through a structured HR department hire all other staff across departments. The GN had the same Premier from February 1999 until November 2008; a new Premier was elected in October 2008. An early order of business was an assessment by the people of Nunavut of the GN - a 'report card' on service delivery. The results have just been received, providing direction for the current administration in moving forward.

The Inuit organizations, including Nunavut Tunngavik Inc, and the regional associations, development corporations and economic development organizations all have their leadership elected by their respective beneficiary groups on a regular basis. Their respective leadership then hires their senior manager who hires the balance of the staff. The leadership of the Institutes of Public Government (IPG) established as a result of the Land Claim - Nunavut Impact Review Board, Nunavut Water Board, Nunavut Wildlife Management Board, and Nunavut Planning Commission - all have board members appointed by the Minister of Indian and Northern Affairs Canada for specific terms, with staff hired and directed by the boards. 


\section{Cs for successful leadership}

As identified in the introduction, there are significant issues related to economic development leadership in Nunavut. In reality, there are a number of structures and processes that provide leadership at the community, regional, territorial and sectoral level. There is a wide range of supports in place to assist communities in planning the development of their community, development in their community and addressing impacts/benefits from development in and around their community. Limitations on the success of implementation at the community level will be examined under four headings - capacity, coordination, collaboration and communication!

Capacity: - Do the individuals involved have the knowledge, skills and abilities to do what needs to be done (elected officials and staff)? Are they in their positions long enough to plan and take action (elected terms and staff retention)? Do the residents of the community understand and support what is required to enact change?

Coordination: - Community leadership, GN leadership - territory-wide and regional, federal leadership, Inuit leadership - territory-wide and regional, sectoral and NGO leadership all need to be involved in development at the community level. They need to be working from the same developmental plan together, at the same time, on the same page. Leadership in this context is not intended to specify the elected individuals, but all of the decision makers both elected and employed.

Collaboration: - In addition to coordination across levels of leadership for a particular community, there is also a need for collaboration in areas of mutual interest, impact or benefit including; adjacent communities, transportation linkages, water shed or resource linkages, jurisdictional or legislative issues.

Communication: - Everyone from the resident to the highest level of leadership must be aware of opportunities and limitations; know that their ideas, concerns and interests are valuable and heard; know what is possible; what is planned; and, what results are expected, and realized. The communication must be across Nunavut, so everyone has access to the information.

\section{Opportunity to action change}

The opportunity exists as the Government of Nunavut develops an action plan to respond to the issues raised in the Report Card and sets about establishing an implementation plan for 'Tamapta' ${ }^{2}$. The Government of Canada is also implementing the Arctic Strategy which

\footnotetext{
${ }^{2}$ Tamapta - Building our Future Together, the mandate of the $3^{\text {rd }}$ Legislative Assembly of Nunavut. http://www.gov.nu.ca/tamapta/tamapta_english.pdf
} 
includes a significant Research Agenda, Arctic Sovereignty initiatives, establishment of the Canadian Northern Economic Development Agency, and others. Nunavut Tunngavik Inc is working to finalize negotiations for the next ten years of implementing the Nunavut Land Settlement Agreement.

The world watched as Nunavut was created in 1999, and continues to watch as Climate Change opens the Northwest Passage, melts the Arctic Ice Cap, opens Arctic waters for exploration and discovery of underwater resources, as jurisdictions jostle for ownership of the North Pole and high arctic areas, and legislate bans on seal hunting, ... the list grows, as does the focus on the north. The better that Nunavummiut and those that provide leadership in Nunavut are able to plan together and work together, the better the chance for economic success.

In many respects the Consensus approach to decision making in Nunavut should be a good fit for the four $\mathrm{C}$ states to be implemented - consensus should require that an informed decision is taken once everyone agrees on the required result. Success will be dependent on the ability to identify a suitable process for cooperative implementation. Sustainability will only be possible with all parties working towards the same goal.

\section{Author biography}

Cheri Kemp-Long is the Regional Economic Development Advisor with the Nunavut office of CanNor a position she has held since 2003. Cheri is Secretary/Treasurer of the Nunavut Economic Developers Association, and Treasurer on the Economic Developers Association of Canada board.

Cheri moved to Iqaluit in 1984 to operate a tourism business; in 1991 she moved to Fort Simpson, NWT for a three year term as Tourism Development Officer for the GNWT. Once completed she spent 1.5 years in Cambridge Bay, NWT in the same position until she returned to Iqaluit to head up Nunavut Tourism. In 2001 Cheri was hired as Economic Development Officer for the City of Iqaluit - it was during that time that she became aware of the EDAC/University of Waterloo programs. She successfully achieved her Ec.D. certification in late 2003, and completed the Year 3 program for $\operatorname{EcD}(\mathrm{F})$ certification in 2009.

In 2008 Cheri completed the core program towards a Bachelor of Circumpolar Studies through the University of the Arctic and in 2010 hopes to complete work towards the University of Waterloo Economic Development Diploma. Continuing education is part of her life!

Cheri and her husband have three of their grown children in Iqaluit with their own families and homes, including three energetic grandchildren to keep them entertained. They vacation on their sailboat near Kingston in Lake Ontario. 
Figure 5. Circumpolar map of the north

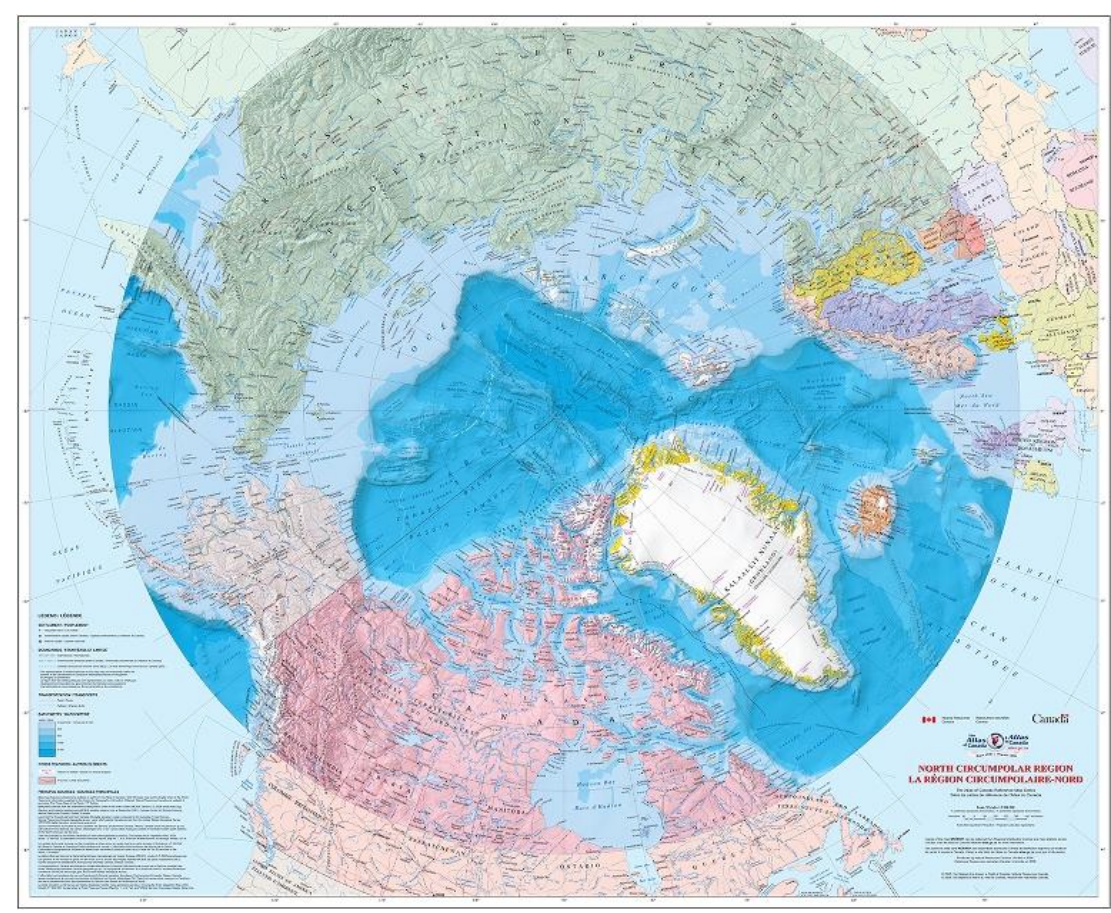

Source: NRCAN (2009).North Circumpolar Region. Retrieved from http://atlas.gc.ca/site/english/maps/thenorth.html

\section{WEB RESOURCES}

Government of Canada

http://www.northernstrategy.ca/index-eng.asp

http://www.north.gc.ca/index-eng.asp

Government of Nunavut

http://www.assembly.nu.ca/english/index.html

http://www.gov.nu.ca/english/

http://cgs.gov.nu.ca/en/

http://www.edt.gov.nu.ca/apps/authoring/dspPage.aspx?page=home

Nunavut Tunngavik Inc site

http://www.tunngavik.com/ 